IJLRES - International Journal on Language, Research and Education Studies

ISSN: 2580-6777 (p); 2580-6785 (e)

DOI: 10.30575/2017/IJLRES-2018050809

Vol. 2, No. 2, 2018

Page: $251-265$

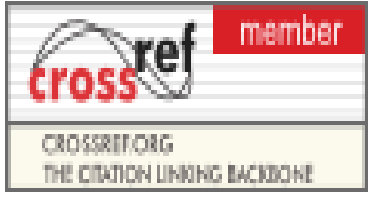

\title{
IMPLEMENTATION OF SCHOOL HEADMASTER'S STRATEGIC MANAGEMENT IN THE EFFORT ON INCREASING THE QUALITY OF EDUCATION AT SENIOR HIGH SCHOOL (SMA) OF UISU MEDAN
}

\author{
Nila Safina \\ Islamic University of North Sumatra, Indonesia \\ nilasafina@gmail.com
}

\begin{abstract}
This research aims to know the effort which is done by principal of school increasing education quality and the implementation of management strategic in SMA UISU Medan. This research used qualitative descriptive method, by using observation technique, interview, and documentation study. Key informant in this research is the principal of a school, and supported by another up to date informational which is needed to this research. Technique of processing data has some steps. First, data which is collected must be identified and classified, the analyzed and it is examined the validity by using triangulation, next each founding from the result analysis is correlated one each other to build one logic arrangement aspect which is applied in SMA UISU Medan. Based on this research, it is found some things: first the effort which is done by principal of a school increasing the education quality in SMA UISU Medan is by formulated strategic management thought make the following program: School review, Banch marking, Quality assurance and Quality control. Second, the application of principal of a school strategic management in the effort to increase education quality in SMA UISU Medan very depend on: (1) Education structure organization, (2) Formulation Ursion, Mission, aim and target of school, (3) State organization strategy, (4) Implementation school organization strategy and (5) Do SWOT analysis. Based on the data found, the writer suggest. Firstly, in the activity of increasing education quality, it is a must that all program quality increasing which has been formulated must have strategy to apply the program, so there is no program which, with the reason not know how to apply. Secondly, all school person that involved with increasing the quality should be given information and told that strategy which is done in increasing the education quality. Third, it is need to form evaluation's team which involved school organization. To examine the program which has formulated, and the examine result of resources should be communicated to all people in the school.
\end{abstract}

Keywords; Head Master's Strategic Management, Increasing the Quality of Education, Senior High School of UISU Medan

\section{INTRODUCTION}

School management varies according to the school's vision, mission and objectives. The principal is expected to have a strong management strategy concept 
hence school goals can be achieved optimally. Therefore, the principal must be able to set goals that are oriented to the future.

SMA UISU is one of the schools whose existence is quite important in supporting educational activities in Medan city. This school seeks to improve the quality of education, among others through various training and improvement of teacher competence, the use of books and learning tools

To achieve the goal of efficient and effective education, it is necessary for teachers who have the competence, facilities, facilities and infrastructure that support such as in SMA UISU Medan. Related to the above, the writer is interested to make the focus of problem in this research is "The implementation of strategic management in improving the quality of education in SMA UISU Medan". Because based on preliminary data that the researchers found in the initial research phase UAN graph from 2015 to 2016 has not been as expected..

\section{LITERATURE REVIEW}

\section{Definition of Strategic Management}

Blanchard says "Management is working or working with and through individuals and groups and other resources to accomplish organizational goals ${ }^{1}$. Selanjutnya, Malayu states that "Management is the science and art of managing the process of utilizing human resources and other resources effectively and efficiently to achieve a certain goal" 2 .

Based on the Malayu study of management, found art and science to regulate the work process in achieving the goal. Differences in individual characteristics in the same or different professional skills make the principal in his function as a manager to foster beautiful and different interpersonal relationships. This beautiful and unique relationship will create a conducive atmosphere and climate in realizing work behavior in achieving the goal.

The comprehensive formulation of the strategy can be explained as follows:

a. Strategy is a consistent and integral decision pattern.

\footnotetext{
${ }^{1}$ Blanchard and Jhonson, 1998. Manajer Satu Menit, (Terjemahan oleh Anha WB), Jakarta, PT Gramedia Indonesia. P. 4

${ }^{2}$ Hasibuan, Malayu, SP, 2003. Manajemen Suber daya Manusia Edisi Revisi, Jkaarta. PT Bumi Aksara. P. 124
} 
b. Define and display organizational goals in terms of long-term goals, program acting and resource allocation priorities.

c. Select the field to be cultivated.

d. Trying to gain long-lasting benefits, by responding appropriately to opportunities and threats from the organization's external environment, its strengths and weaknesses.

e. Involves all levels of the organization ${ }^{3}$.

Castler stated that "Strategic management is that set of managerial decisions and action that determines the long-run performance of corporation. It includes environmental scanning, strategy formulation, strategy implementation, and evaluation and control".4

In another view, the strategy is prepared by considering the strategic environmental factors both internal and external an education, and accommodate the interests in it to achieve the goal. Thus management strategy is an art using the skills and resources or organization in the education unit by considering internal and external factors to achieve the target through an effective relationship with the environment in the most favorable conditions 5 .

Based on some understanding above, it can be concluded that in formulating and preparing management strategy, organization must have: 1) vision, mission, goals and targets to be achieved, 2) identifying internal and external environment of organization, 3) conducting various useful analysis in maintaining customer trust, 4) making strategic alternatives, 5) making alternative strategies selected and 6) creating a feedback system to know the effectiveness of achieving the implementation of strategic management.

For more details the stages of the strategic management process can be seen in Figure 1.

${ }^{3}$ Hanafiah, Yusuf, M and Sukarna, 1994. Pengelolaan Total Pendidikan Tinggi, Depdikbud RI. P. 65

4 Castler, Williem B, 1996. The Human Resource Function in Education. Boston: Allyn and Bacon. P. 187

${ }^{5}$ Gultom R, 2008. Kepemimpinan Transformasi Berbasis Mutu Pendidikan, Medan, USU Press. P. 176 


\section{Elements of Strategic Management}

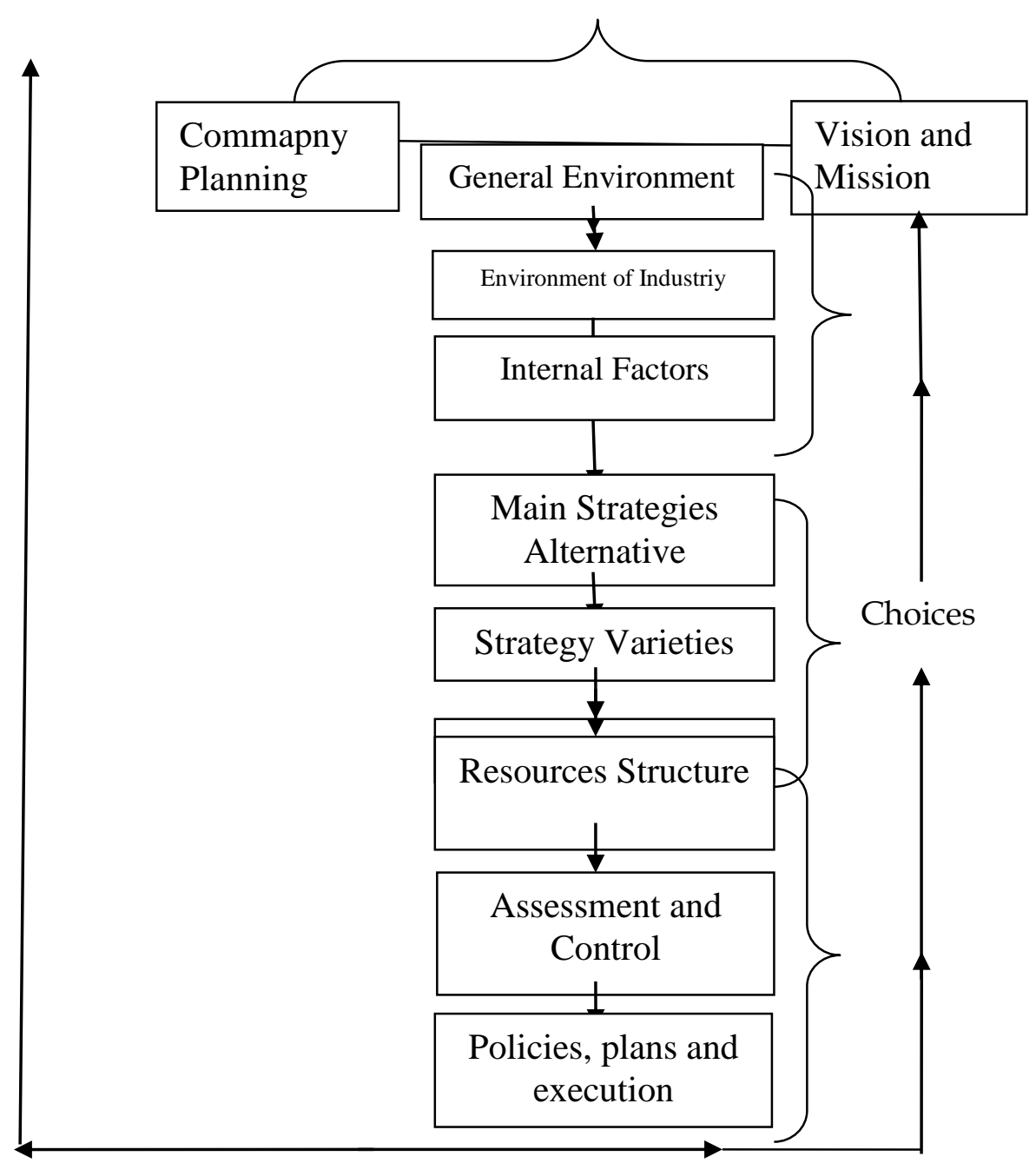

Figure 1. Management Strategic Model

\section{Implementation of Strategic Management for Head Master}

In the implication, the principal is a top manager in a school, therefore the principal must be able to make the organization he leads more proactive rather than reactive to initiate and influence the activities in the context of improving the quality of learning.

In management, an organization needs to divide the tasks and functions of each party involved in managerial activities in the organization. The division of labor and the delegation of authority is one of the tasks of the principal as a top manager. The principal nurtures teachers to perform their professional duties optimally.

The delivery of education and teaching is a management activity that involves various aspects within and influenced by the internal environment and the external 
Implementation Of School Headmaster's Strategic Management In The Effort On Increasing The Quality Of Education At Senior High School (Sma) Of Uisu Medan DOI: 10.30575/2017/IJLRES-2018050809

environment. The management of educational institutions is carried out covering the scope of planning, organizing, organizing and supervising various aspects. Teaching and learning activities in educational and educational institutions are managed by optimizing existing resources such as facilities and infrastructure, human resources, funds and students.

\section{a. Facilities and infrastructure}

Facilities and infrastructure in educational institutions include buildings, equipment, furniture and books that meet the needs of education. The use of educational facilities must be managed in an orderly manner, without adequate facilities of practice, the science that will be obtained by students will only be theoretical that leads to verbalism.

\section{b. Human Resources}

In general, human resources are the key to the success of an organization. Other elements will not function optimally without reliable human resources in managing them. In this case the teacher is an important element in improving the quality of education, then professional teacher training needs to be improved by attending trainings, seminars, and comparative studies both within the city and outside the city, so that teachers have a broad insight.

\section{c. Funds}

Quality education costs a lot. The community participates in the financing of education. School relations with the community will grow if the community also benefits from participation in the school program. Benefits can be interpreted widely, including a sense of attention and satisfaction, because it can help the interests of school.

\section{d. Students}

Students are one of the resources produced by the school. In the educational program, teaching and learning activities are directed to the realization of the learning process thoroughly and can spur students active and creative. Students are encouraged to improve their intellectual and emotional intelligence (IQ, EQ, SQ) in a balanced way and improve the efficiency and activity of the learning process.

The results obtained by students after completing the educational process is a direct result of education. This result is knowledge, attitude and skill. This result is often 
used as a criterion of educational success in terms of quality. This direct result is used the starting point of measuring the quality of education of an educational institution.

\section{METHODOLOGY}

\section{Research Approach}

This research uses descriptive qualitative approach. The selection of this method is based on the consideration that what to look for is data that gives a picture and describes a complex social reality to be concrete. Social situation in accordance with the context is diluksikan until found the behavior of the main respondents Implementation of Principal Strategic Management In Efforts to Improve the Quality of Education in Senior High School of UISU Medan.

Further Bogdan and Biklen suggests there are five characteristics of qualitative research as follows:

1) Qualitative research has the natural setting as the direct source of data the researcher is the key instrument,

2) Qualitative research is descriptive,

3) Qualitative research are concerned with process rather than simply with outcomes or product,

4) Qualitative researches tend to analyze their data inductively

5) Meaning is of essential concern to the qualitative approach 6 .

Of these various considerations, this research is not merely collecting data, but rather an approach to the empirical world. A variety of field behaviors and situations become something that must be studied in depth to its core behavior.

\section{FINDINGS AND DISCUSSION}

\section{Implementation of Principal Strategy Management in Efforts to Improve the Quality} of Education at SMA of UISU Medan.

Achievement of organizational goals that the improvement of the quality of education is very necessary tool that acts as an accelerator and dynamicator so that goals can be achieved effectively and efficiently. In line with the tesebut, the strategy is

${ }^{6}$ Bagdan, Robert C \& Biklen Sari Kaopp, 1992, Qualitative Research for Education; An Introduction to Theory and Methods, Boston, Allya and Bacon, Inc. p. 29 
believed as a tool to achieve goals. Before discussing the organizational goals, the principal says that every teacher and employee should know what management and management mean. This is as revealed in the following interview (data 10):

"In order to achieve organizational goals it is imperative that strategies be developed, therefore, before reaching the discussion of the organizational goals of employees and teachers should understand and know what the real nature of management and strategic management".

Furthermore the principal said his opinion on what management and management strategy is, this is expressed in the following interview (data 11):

"Management science is the process of planning, organizing, controlling, and supervision needed to achieve the objectives that have been set, while the management strategy is a series of decisions and fundamental actions made by top management through a systematic approach and implemented by all organizai ranks in order to achieve goals sustained goals".

In addition to the principal, the vice principal (PKS 2) also gave his opinion on management and management of the strategy, it was expressed in the following interview (data 12:

"Management science is a process of cooperation between one person with others to achieve the goals set previously. The process undertaken in the form of planning, organizing, pandering, budgeting, coordination. While strategic management is a systematic approach that coordinates the organization that is ensured to achieve a sustainable goals".

Furthermore, one teacher (teacher 1) represents another teacher saying his opinion about strategic management summarized in the following interview (data 13):

"Management science is the control of resources that require planning, organizing, budgeting, supervision, direction, and coordination to achieve predetermined educational goals".

Based on the principal's knowledge, vice principals and teachers on the definition of strategic management, the principal said that UISU Senior High School must have special strategic management in improving the quality of education. This is as revealed in the following interview (data 14):

"UISU Senior High School has a special strategic management in improving the quality of education, because the school is an organization that there is one togetherness and interaction and interdependence of individuals who work together to achieve a goal. Therefore I involve school personnel in implementing programs that have been established by the school". 
Then the principal resumes his conversation about the activity-activities that are being performed as an application of the planned strategy management, the activity is delivered in the following interview (data 15):

"The activities I undertake in applying strategic management include: 1) monitoring and evaluation to ensure that planned programs can be planned for the purpose, this evaluation is described in the analysis that has been prepared. 2). Conducting regular meetings with teachers in formulating school vision and mission, objectives and taeget of schools, determining and implementing school organizational strategy 3). Contains an education supervisor to provide input to the teacher".

Furthermore, Vice Principal 1 said that the special strategic management that has been done in UISU High School amongst the SWOT analysis is to look at the advantages and weaknesses, opportunities and constraints faced by SMA UISU. This is as expressed in interview (data 16) below:

"Specific strategic management undertaken in UISU Senior High School among others is compiling SWOT analysis to see the weaknesses and strengths, opportunities and constraints faced by UISU High School applied in evaluation. In addition, the principal together with teachers held a routine on the formulation of school vision and mission, the determination and implementation of the organization's strategy for the future schoo".

Furthermore, one of the teachers (teacher 2) said that the strategy management done at UISU High School is as summarized in the interview (data 17):

"The strategy management that has been done in SMA UISU is by conducting monitoring and evaluation compiled in SWOT analysis, to know more about the strengths / advantages, weaknesses, opportunities and constraints faced by schools and the things that must be prepared to overcome the things that appears in the SWOT analysis that has been compiled".

All teachers should know the programs that have been formulated in the management strategy to improve the quality of education at UISU High School, because all teachers should be involved in the implementation of strategic management in schools. This is as described by the principal in the interview (data 18) below:

"All teachers must know the program that has been formulated in the strategy management in improving the quality of education in SMA UISU, because all teachers are involved in the implementation of strategy management. The involvement of teachers in implementing strategic management in schools such as providing teaching tasks according to the discipline of teachers, providing knowledge about educational innovation to teachers, involving teachers in seminars, intensifying MGMP meetings, complementing the means of learning infrastructure and complementary learning media, so teachers can teach and achieve the learning objectives well and minimize the barriers in teaching, while for the employees are given training and upgrading in terms of administration".

In line with what one PKS I said, all teachers need to know the management strategies that have been developed, because all teachers should be involved in the 
implementation of strategic management in schools. This is as summarized in the following interview (data 19):

"All teachers and employees are aware of the management strategies implemented in the school as all teachers and staff will be involved in the implementation of strategic management in schools. The involvement of teachers and employees such as: teachers are given authority by the principal to teach in accordance with educational background, sending teachers to follow the training in accordance with the field of study, cultivated mamximalkan media and learning infrastructure while for employees in accordance with their duties implement school administration".

Then one teacher (teacher 1) said that indeed all teachers and staff should know the programs that have been developed as management strategies in the school, because teachers and employees must be involved in it. This is as summarized in the following interview (data 20):

"All teachers and employees know the programs that have been developed as strategic management in the school, because teachers and employees will definitely be involved in it. Certainly the involvement of teachers and employees in accordance with the task of teaching the teacher according to the field of study and discipline of science, followed a scientific seminar or training in accordance with the field of study and employees carry out school administration".

Until now there are some obstacles encountered in high school UISU in the implementation of strategy management in improving the quality of education. This is as revealed by the principal in the following interview (data 21):

"The obstacles encountered in implementing the strategy management that have been implemented are such as funding, and teacher change of subject area. To overcome this, the temporary solution is to recruit new teachers and be trained, to include alumni of the community and parents so that they care about improving the quality of education"

The expression of the principal above is in accordance with what is expressed by Vice Principal 2, as summarized in the following interview (data 22):

"Constraints in implementing strategic management that has been implemented to date is the subject of teacher change in the field of study and funding issues. And the temporary solution is to recruit qualified teachers".

Thus, strategic management, based on the principal version of the headmaster, deputy headmaster and teacher at UISU High School, is the process of planning, organizing, controlling, and monitoring and evaluation necessary to achieve the predetermined educational objectives while strategic management is a series of decisions fundamentals made by top management through a systematic approach and implemented by the whole range of organizations in order to achieve the goal of sustainable success. 


\section{Leadership for Education Quality}

The requirement to become a principal certainly can not be seen only from the administrative aspect, which meets the requirements of the class, term of employment, seniority and others. But the requirement to be a principal should be considered and supplemented by monitoring supervisors and educational experts about their eligibility to occupy the principal's office, in addition to the support of teachers and the community. The importance of educational background as an illustration of academic ability is also important, as it has the assurance that the school has wide insight and high competitive power.

Educational leaders are principals who can influence their subordinates to work together to achieve what is intended. This was revealed by one of the teachers in the interview (data 23) below:

"Educational leaders are principals who can influence their subordinates to work together to achieve what is targeted by educational institutions that is improving the quality of education".

Educational leaders are leaders who are sensitive to educational and creative innovations, as one teacher expressed in the following interview (data 24):

"Educational leaders are leaders who are sensitive to educational innovation, must be creative and proactive toward the demands of the times and oriented towards improving the quality of education".

One of the teachers said that in order to create the quality of education in schools, it takes a leader in it. This is as revealed in the interview (data 25) below:

"Yes it is true, in order to create the quality of education in schools would require leaders in it, the principal who berkompetensi guiding and managing teachers, employees and resources that exist at the school. Such resources may be natural and human, such as exploiting the ability of employees and teachers who are considered capable of carrying out the task and achieve the vision that has been formulated ".

Furthermore, other teachers say that in order for schools to have the quality of education then the school must have leaders who can lead, smart and dignified and diligent supervising subordinates, supervising the class and what is in school. This is what he expressed in interviews (data 26) below:

"In my opinion that the school has the quality of education, the principal should be able to lead subordinates, meaning that subordinates should be able to nurut him, or affect his subordinates. Then must be smart, both in academic terms and in associating with his subordinates and dignified, respected subordinates, meaning authoritative teachers respect him but teachers are not afraid to exchange ideas with him and the principal should be diligent monitoring in the whole class either before the lesson begins or when 
the lesson begins with so the principal will know whether the difficult class is ready to be used for study or not and so the principal can know the shortcomings that existed during the learning process implemented".

Leaders are needed for the quality of education is achieved that educational leaders who understand the quality of education and how to achieve it. This is as one teacher expressed in the interview (data 27) below:

"Leaders are required for the quality of education is achieved that educational leaders who understand about the quality of education is the principal of a successful and effective, successful principals are able to embrace teachers and employees on improving the quality of education of quality students and graduates of quality".

In order for the quality of education can be achieved, it takes effective leadership that has the vision and mission. This is as expressed by the vice principal in the interview (data 28) below:

"Leaders are needed for the quality of education can be achieved then required an effective leader who has a vision and mission and can put it in clear policies".

In order for the quality of education can be achieved then required a firm leader and have a commitment. This is as expressed by one of the teachers in the interview (data 29) below:

"In order for the quality of education can be achieved then required a firm leader and have a commitment and responsible in the process of improvement of educational institutions".

What distinguishes educational leaders from other leaders is the vision that has been formulated. This is as expressed by the principal in the interview (data 30) below:

"What distinguishes educational leaders from other leaders is the vision that has been formulated by each leader. Because the vision will determine how long an organization will last. Typically educational leaders can formulate the best possible vision so that the organization they lead can survive, although the vision is only as a destination to be addressed, but the vision is not a dream but the ideals to be achieved.

So leadership to achieve the quality of educators"

\section{Working Group to Achieve Quality}

Working Group to achieve quality / quality control clusters are small groups that conduct quality control and quality, regularly, voluntarily and continuously in their work activities by applying quality control principles and techniques.

The principal thinks that the working group to achieve the quality is a group to achieve the quality. This he said in interview 31 data below: 
"The working group to achieve the quality is a group to achieve the desired qualities by groups or educational institutions such as the Subject Teachers Consultative Conference (MGMP), established to achieve quality or completion and success in each subject".

Next the vice principal added about the quality work group is a team in dealing with an improvement. This is stated in the following interview of 32 data:

"The quality work group is a team in dealing with an improvement or development of educational quality in which the team employs teachers and employees and provides greater responsibility".

The steps that must be done by the team team in pursuing the quality of education is as expressed by the principal in the following interview:

"The steps that must be done by the team team in pursuing the quality of education is to form groups or teams both large and small, giving opinions for various problems and the establishment of work rules on the group or team".

The principal expressed by the school principal was added by the vice principal that the steps that the group should take in pursuing the quality of education are as listed in the following 33 data interviews:

"The steps that the team should take to pursue the quality of education is to deliberate by forming a team such as the MGMP and determining the MGMP Teachers Working Group (MKG) schedule. Each MGMP determines the steps to be taken to improve the quality of education such as determining Minimum Rating Standards (SPM) to determine the learning method of each material and so forth ".

Therefore, the working group to reach the quality or the quality control group that is done in SMA UISU Medan is to form a team of small and big scale like MGMP and make a schedule of KKG to do musyawarah which in there is brainstorming to solve a problem.

\section{School Strategic Management in Efforting the Improvement of Education Quality}

The implementation of school strategy management involves a major effort aimed at transforming strategic goals into action: school programming. No matter how great a strategy, if not implemented, of course, that strategy will not be meaningful for school development.

Therefore, the ability of school principals and other school personnel to implement a strategy in the management of school strategy is very important in relation to the skill of the principal as a leader and teacher as professionals responsible for the learning progress of learners. In fact implementation of strategy especially in school is not easy to do. Generally the school stuck on the routine activities of teachers entering 
the class member lesson pendekatnnya same as before, carrying exams, members of the exam results and ultimately learners graduate with quality improvise.

The facts mentioned above do not occur in SMA UISU, even if it happens very small because the principal as a leader in high school UISU has compiled school programs that must be run. This is as expressed by the headmaster in interview 34 of the following data:

"In implementing this strategy management I have developed a gradual program of schools, such as short-term programs, medium-term programs and long-term programs".

The programs that have been prepared are implemented in stages, such as completing the library books and then completing the science laboratory. This is revealed by the principal in the following interview (data 35):

"The programs that have been prepared are implemented gradually, for example completing the library books then equip the science laboratory, in addition to the programs that I have planned in implementing this strategic management such as; improving the professionalism of teachers by involving training both conducted by schools regularly or implemented by the Education Office of the City and Provinces, increasing the value of national examinations of students so that every year the higher the value, increasing the number of graduates every year into public universities".

In line with the above matters PKS I said that the principal has developed a program to mengimplemmentasikan management strategy. This is as revealed in the following awrahcara (data 36).

"To implement the principal's management strategy has developed a gradual, short-term, medium- and long-term gradual school program such as completing library books and then accompanying the science laboratory and improving the scores of high national exam scores".

Furthermore, one teacher (teacher 2) said that the programs that have been prepared by the principal is the embodiment of management strategy, this is as summarized in the interview (data 37).

"In implementing the management of this strategy the principal makes a gradual school program, for example completing library books, equipping science laboratories, improving the professionalism of teachers by including training both in schools regularly or by city education agencies as well as provinces, and improve the achievement of national exam scores so that each year the value of the higher values ".

In addition to the above, the strategy undertaken in SMA UISU Medan in preparing the quality improvement program of education is done by applying 4 techniques, this is as expressed by the principal in the interview (Data 38) follows:

"There are 4 techniques done by UISU High School in developing education quality improvement program, that is; a process in which all components of the school work 
together in particular with parents and professionals to evaluate and assess school effectiveness, and the quality of graduates, and undertake an activity to define the standards and targets to be achieved within a given period, and to have a technique to determine that the educational process has taken place as it should, to perform quality control such as a system to detect the occurrence of deviation of output quality that is not in accordance with the standard. Quality control requires clear and definite quality indicators, so that quality deviations can be determined ".

Thus, in implementing strategic management, the principal has made a gradual school program, in short-term programs, medium-term programs and longterm programs. Programs prepared such as completing library books then equipping science laboratories, enhancing the professionalism of teachers by including training both in schools conducted routinely and by city and provincial education offices, increasing the pro- gramme of the national exam scores so that each year the acquisition of value the higher, and increasing the number of graduates every year to enter the state universities.

\section{CONCLUSION}

Every strategy demands its implementation, without implementation it has no meaning whatsoever. In UISU Senior High School principals nurture teachers to have measurable performance in the learning process to achieve the goals programmed by school managers. This means there is a process of coordination between the principal and teachers in realizing the school curriculum.

Talking about the quality of education means examining the whole educational dimension with each other interrelated. In addition, determining the characteristics or measurements shows the quality of education is very complicated, but some indicators can be used as ramboo, they are; student learning achievement, supporting facilities and infrastructure, teaching quality and school management.

\section{BIBILIOGRAPHY}

Akdon, 2006. Stategic management For Educational Management (Manajemen Strategik Untuk Manajemen Pendidikan). Bandung; Alfabeta

Alma Buchori. 2002. Pengantar Bisnis. Bandung: Alfabeta 
Implementation Of School Headmaster's Strategic Management In The Effort On Increasing The Quality Of Education At Senior High School (Sma) Of Uisu Medan DOI: 10.30575/2017/IJLRES-2018050809

Anwar. Qomari. 2004. Manajemen Strategik Pengembangan Sumber Daya Manusia Perguruan Tinggi, Jakarta; Uhamka Press.

Atmosudiro, Prajudi S. 1985. Dasar-Dasar Ilmu Administrasi. Jakarta: Gramedia

Blanchard and Jhonson, 1998. Manajer Satu Menit, (Terjemahan oleh Anha WB), Jakarta, PT Gramedia Indonesia

Bagdan, Robert C \& Piker Sari Kaopp, 1992, Qualitative Research for Education; An Introduction to Theory and Methods, Boston, Allya and Bacon, Inc.

Castler, Williem B, 1996. The Human Resource Function in Education. Boston: Allyn and Bacon.

Danim, Wiliam B. 2002. Inovasi Pendidikan Dalam Upaya Peningkatan Profesionalisme Tenaga Kependidikan, Bandung. Pustaka Setia

Faisal, Sanafiah, 1990. Penelitian Kualitatif. Malang: Y A 3

Gultom R, 2008. Kepemimpinan Transformasi Berbasis Mutu Pendidikan, Medan, USU Press.

Hanafiah, Yusuf, M and Sukarna, 1994. Pengelolaan Total Pendidikan Tinggi, Depdikbud RI

Handoko, T. Hani, 1994. Manajemen Edisi 2. Yogyakarta; BPFF

Hasbulla. 2006. Otonomi Pendidikan, Jakarta, PT. Raja Grapindo Persada

Hasibuan, Malayu, SP, 2003. Manajemen Suber daya Manusia Edisi Revisi, Jkaarta. PT Bumi Aksara. 